\title{
Sarah Hutton, British Philosophy in the Seventeenth Century, Oxford University Press, 15, pp. 297
}

DOI: http://dx.doi.org/10.12775/RF.2015.018

The time that has passed and separates us from the philosophical achievements of the seventeenth-century causes a particular change in perspective according to which it is easy to attribute a specific intellectual formation or an area of science or philosophy to modern thinkers. This is made easier still by the fact that still feel a bond with this age the times in which the great philosophical systems of R. Descartes, B. Spinoza or G. Leibniz arose. It is also because of the scientific revolution, during which, thanks to R. Boyle or I. Newton, modern natural sciences were born. Although we are used to treating Descartes or Hobbes today primarily as philosophers, and Boyle and Newton as researchers funding modern sciences, such a picture of their achievements greatly simplifies matters. Descartes' interest in natural science or Hobbes' interest in mathematics are usually mentioned marginally, as well as Boyle's and Newton's philosophical and theological works. And, although the errors in Cartesian natural philosophy and in Hobbes' writings on mathematics were fairly quickly revealed, it does not invalidate the fact that such selective treatment of intellectual history leads to a somewhat false as a result of looking at it through the prism of later times. This is also evidence, with regard to the philosophy of the seventeenth century, that there was no strict border between philosophy, theology and the scientific description of nature. Such a selective look often neglects the importance of ongoing discussions and the relationships between particular achievements of philosophers which gives us the impression that each thinker inhabited a lonely island.

In the latest research on modern British philosophy, a lot has been made to show its more nuanced image by discussing the philosophical systems in various, complementary contexts: biographical, scientific or social. The works by Michael Hunter dedicated to Boyle, by Stephen Gaukroger dedicated to the relationship between 17th century philosophy and natural sciences, by Quentin Skinner on modern political philosophy, or by Stephen Shapin on social determinants of modern thoughts 
bring a rich picture of the intellectual background in which seventeenthcentury British philosophy developed. The studies by Sarah Hutton which focus on the Cambridge Platonists (especially Henry More and Ralph Cudworth) and the role of women in the history of philosophy (Anne Conway, a Woman Philosopher, 2004) also follow this trend. Hutton additionally published new editions of the writings of Cudworth and Conway and edited several volumes of essays on the philosophy of Locke, Newton, the Cambridge Platonists and other thinkers gathered around the Dutch Quaker, merchant, and book collector, Benjamin Furly. In 2015 Hutton released her latest work. British Philosophy in the Seventeenth Century is a compendium of knowledge about the philosophy of this period, which situates it in a very wide intellectual context. It provides a panoramic presentation of this subject and, in many respects, is a trailblazing examination of the period. This innovative work includes a reconstruction of the importance of the role of minor philosophers (especially women) entangled in the intellectual milieu of that period, as well as shows those aspects of the activities of the philosophers which have been through the history moved into the shadow. Most importantly, a reconstruction of the multiple relationships between the leading thinkers and intellectuals who played the role of intermediaries between the greatest minds of the era (such as named Benjamin Furly, Locke's and Shaftesbury's friend, or Henry Oldenburg, the secretary of the Royal Society) and had a significant impact in the exchange of philosophical ideas.

Sarah Hutton's work is not analytical and does not reconstruct the grid of concepts and categories used within a single philosophical system or in wider intellectual movements. It also does not show the emergence and shaping of selected philosophical problems, the importance of which is visible only from a later perspective. Both approaches are only seen in the background of her work and are complementary to the basic approach that Hutton describes as a "conversational model" of an intellectual history. Opposing a simplified labeling in which philosophers are usually divided usually into empiricists and rationalists, epigones and those who belong to the intellectual avant-garde, Hutton asks the reader to listen to the individual voices of the debate attentively, and thus draws attention to the social and political determinants of particular intellectual solutions. She writes: "I focus on individuals rather than particular branches of philosophy, or philosophical themes, and I treat celebrate 17th-century philosophy as an ongoing conversation, as a means of setting philosophers in relation to one another....The conversational model allows voices to be heard which would otherwise be discounted. By this means I provide what might be called a 'thick description' of seventeenth-century intellectual culture, setting marginal and 'major' thinkers within a more integrated account of seventeenth- 
century philosophy which attempts to view it in its own terms, taking account of institutions, and the modes of circulation of ideas." (p. 2).

Unlike Steven Shapin, another researcher of early modernity, Hutton treats the social conditions of knowledge as a significant factor in its development although, not a primary or dominant one. Hence the description of the functioning of the nineteenth century universities, of the processes of widening the circle of authors or the description of the 17th century readership are a valuable complement to the essential problem analysis. Still, the philosophy is treated as an independent whole, and not as a result of spontaneous social relations.

The book consists of two essential parts. The first outlines the background of the philosophical debates; here Hutton seems to use the method of gradual approximations. Determining the nature of the transformations taking place within the century is made from afar (juxtaposing Case and Shaftesbury, the former living at the beginning of the period and the latter at its end, demonstrates the process of departing from Aristotelianism and the birth of moral philosophy which was typical for the next century), whereas the description of the changes in various fields of philosophy and its relationships to theology and the study of nature is made from a lesser distance. A closer look brings the already mentioned contextual analysis - university curricula or libraries' content - that allows us to reconstruct the conditions for the development of knowledge and show its current importance, sometimes different from the one described in standard textbooks of the history of philosophy.

In the second part of the work, where one can read the views of individual philosophers, this difference in perspectives is even more visible. This is due to the fact that the importance of the achievements of seventeenth-century philosophy was interpreted differently at the time that it was created, and later, during heated debates, when its ahistorical sense was brought out. One can talk about the difference even in the case of the three philosophers who were working almost simultaneously and from whom the intellectual times of the seventeenth century start. Thanks to the significance of their own philosophical endeavours, Francis Bacon and Thomas Hobbes overshadow the figure of the third of them - Herbert of Cherbury. He is known primarily from the allegations on his concept of common notions which fulfill the first book of Locke's Essay Concerning Human Understanding. Meanwhile, convinces Hutton, like the other two, Herbert was treated in the seventeenth century as a philosopher of great importance. Even if criticism of P. Gassendi, R. Descartes or J. Locke was not unfounded, his assimilation of Platonism and his religious rationalism have proven to be durable and influential. However, they did not bear fruit until the works of the Cambridge Platonists and turn-of-the-century deists. Sarah Hutton was well aware of the need to apply a double lens when evaluating the ac- 
cessibility of thinkers of the early modernity. Although the first of them brings a rich and vivid picture of seventeenth-century thought, this does not mean that we can dispense with the assignment of different meaning, depending on the development process and verification of individual accomplishments in history. The reconstructive task which Hutton undertakes is accompanied by the awareness that, although many figures are still worth discussing, the bitter verdict of history has not been completely unjust. Examples include the half-forgotten but interesting philosophers: Herbert of Cherbury, Robert Burthogge, Arthur Collier and John Norris. Hence separate chapters have been devoted to Hobbes and Locke, while the thought of others, inter alia of Boyle or Newton, has been reported on the occasion of the discussion of the wider intellectual processes, such as the emergence of modern science. Seventeenth century British philosophy as a whole is shown in relation both to other achievements of the era (e. g. the continental tradition of Descartes and Malebranche), and the earlier and later philosophy (setting aside Aristotelianism and the emergence of the Enlightenment).

With all its erudition, Sarah Hutton's book is written very clearly. A focus on historical detail while revealing the links between less significant thinkers is accompanied with a concern for the reader who is gradually being introduced in the era. Thanks to the clear division of the volume into individual parts, as well as to the shortness of the presentation, the reader does not become lost in a stream of facts and names. Additionally, added bibliographic guidance that help the reader become acquainted with the specific studies and the various interpretations of these phenomena are also helpful. British Philosophy in the Seventeenth Century meticulously combines a comprehensive monograph with the shortcuts and accessibility of a textbook. It sets an example in presenting the history philosophy in a way that highlights its dynamism and the continuity of the themes undertaken in it. Finally, the book by Sarah Hutton is just a gripping and fascinating read. 